\title{
Peningkatan Prestasi Belajar Bahasa Indonesia Materi Pokok Teks Eksposisi di Kelas X IPA 2 SMA Negeri 1 Sembawa Kabupaten Banyuasin.
}

\author{
Fitriyana Mawarni, Yessi Fitriani \\ Email: fitriyanamawarni@gmail.com , yessifitriani54@yahoo.com \\ Guru SMA Negeri 1 Sembawa \& Dosen UPGRI Palembang
}

\begin{abstract}
Abstrak- Penelitian ini dilatar belakangi masih rendahnya prestasi belajar siswa yang dapat dilihat dari hasil tes (ulangan harian). Berdasarkan hal tersebut dapat pula diidentifikasi beberapa masalah yang menyebabkan rendahnya prestasi belajar siswa, diantaranya dirumuskan sebagai berikut : Apakah hasil belajar siswa pada mata pelajaran Bahasa Indonesia materi pokok Teks Eksposisi dapat ditingkatkan melalui penerapan model pembelajaran mencari informasi (information search). Adapun tujuan penelitian ini adalah menemukan suatu model pembelajaran yang efektif, disenangi siswa dan dapat meningkatan prestasi belajarnya. Prosedur yang ditempuh dalam penelitian ini, diawali dengan melakukan refleksi terhadap proses dan hasil pembelajaran. Selanjutnya dilakukan diskusi dengan teman sejawat mengenai kekurangan-kekurangan dalam proses pembelajaran yang perlu dilakukan perbaikan. Hasil diskusi dalam bentuk saran perbaikan pembelajaran yang menjadi acuan dalam melaksanakan program perbaikan pembelajaran melalui Penelitian Tindakan Kelas (PTK). Pelaksanaan perbaikan dilakukan dalam 2 siklus pembelajaran pada mata pelajaran Bahasa Indonesia.
\end{abstract}

\section{Kata Kunci : Model Pembelajaran Mencari Informasi, Prestasi Belajar}

Abstract- The background of this research is still low student achievement that can be seen from the results of tests (daily tests). Based on this it can also identify some problems that lead to poor performance of student learning, including formulated as follows: Is the student learning outcomes in Indonesian Language subject matter Exposition Text can be improved through the application of learning models looking information (information search). The purpose of this research is to find an effective learning model, favored students and can increase academic achievement. The procedure adopted in this study, begins with a reflection on the learning process and results. Further discussions with colleagues about the deficiencies in the learning process that needs to be improved. The results of the discussion in the form of suggestions for improvement of learning to be a reference in implementing the improvement program of learning through action research (PTK). Implementation of the repair is done in 2 cycles of learning on the subjects of Indonesian.

\section{Keywords: Models of Learning for Information, Learning Achievem}

\section{PENDAHULUAN}

Prestasi belajar adalah hasil belajar yang dicapai oleh seseorang setelah ia melakukan perubahan belajar, baik di sekolah maupun di luar sekolah. Di dalam websters's New International Dictionay mengungkapakan tentang prestasi yaitu; "Achievement test a standardised test for measuring the skill or knowledge by person in one more lines of work a study" (Webster's New Internasional Dictionary, 1951 : 20)

Mempunyai arti kurang lebih prestasi adalah standart test untuk mengukur kecakapan atau pengetahuan bagi seseorang didalam satu atau lebih dari garis-garis pekerjaan atau belajar. Dalam kamus populer prestasi ialah hasil sesuatu yang telah dicapai (Purwodarminto, 1979 : 251) http://belajarpsikologi.com/pengertian-prestasi-

belajarl

Di Sekolah, prestasi belajar tersebut diperoleh melalui proses pembelajaran. Pembelajaran yang sering diidentikkan dengan kata "mengajar" berasal dari kata dasar "ajar" yang berarti petunjuk yang diberikan kepada orang supaya diketahui (diturut) ditambah dengan awalan "pe" dan akhiran "an menjadi "pembelajaran", yang berarti proses, perbuatan, cara mengajar atau 
mengajarkan sehingga anak didik mau belajar. (https://id.wikipedia.org/wiki/Pembelajaran)

Walaupun mempunyai konotasi yang berbeda, dalam konteks pendidikan guru mengajar supaya peserta didik dapat belajar dan menguasai isi pelajaran hingga mencapai sesuatu objektif yang ditentukan (aspek kognitif), juga dapat mempengaruhi perubahan sikap (aspek afektif), serta keterampilan (aspek psikomotor) peserta didik.

Pengajaran memberi kesan hanya sebagai pekerjaan satu pihak, yaitu pekerjaan guru saja. Sedangkan pembelajaran juga menyiratkan adanya interaksi antara guru dengan peserta didik. Pembelajaran adalah suatu sistem yang bertujuan untuk membantu proses belajar siswa, yang berisi serangkaian peristiwa yang dirancang, dissun sedemikian rupa untuk mempengaruhi dan mendukung terjadinya proses belajar siswa yang bersifat internal. Gagne dan Briggs (1979:3).

Dalam Undang-Undang Nomor 20 Tahun 2003 Tentang Sistem Pendidikan Nasional, tujuan penyelenggaraan pendidikan adalah untuk berkembangnya potensi peserta didik agar menjadi manusia yang beriman dan bertakwa kepada Tuhan Yang Maha Esa, berakhlak mulia, sehat, berilmu, cakap, kreatif, mandiri, dan menjadi warga negara yang demokratis serta bertanggung jawab.

Selanjutnya dalam pasal 1 ayat 1 , disebutkan bahwa pendidikan adalah usaha sadar dan terencana untuk mewujudkan suasana belajar dan proses pembelajaran agar peserta didik secara aktif mengembangkan potensi dirinya untuk memiliki kekuatan spiritual keagamaan, pengendalian diri, kepribadian, kecerdasan, akhlak mulia, serta keterampilan yang diperlukan dirinya, masyarakat, bangsa dan Negara, dan pada ayat 20 disebutkan bahwa pembelajaran adalah proses interaksi peserta didik dengan pendidik dan sumber belajar pada suatu lingkungan belajar.

Dalam Kurikulum 2013 (K-13), paradigma pembelajaran yang berpusat pada guru diubah menjadi pembelajaran yang berpusat pada siswa. Pembelajaran Berpusat Pada Siswa (Student Centred Learning) merupakan pendekatan Pembelajaran Kurikulum 2013 tertuang secara jelas dalam Permendikbud No. 81A tentang Implementasi Kurikulum 2013. Pada dokumen regulasi tersebut Pembelajaran Berpusat Pada Siswa (Student Centred Learning) sebagai ciri Pembelajaran Kurikulum 2013 perlu diikuti dengan penyempurnaan pola pikir (mindset) sebagai berikut (Permendikbud No. 69 Thn 2013) :

1. Perubahan dari pola pembelajaran satu arah (interaksi guru-peserta didik) menjadi pembelajaran interaktif (interaktif gurupeserta didik-masyarakat-lingkungan alam, sumber/ media lainnya).

2. Pola pembelajaran terisolasi menjadi pembelajaran secara jejaring (peserta didik dapat menimba ilmu dari siapa saja dan dari mana saja yang dapat dihubungi serta diperoleh melalui internet).

3. Pola pembelajaran pasif menjadi pembelajaran aktif-mencari (pembelajaran siswa aktif mencari semakin diperkuat dengan model pembelajaran pendekatan sains).

4. Pola belajar sendiri menjadi belajar kelompok (berbasis tim).

5. Pola pembelajaran alat tunggal menjadi pembelajaran berbasis alat multimedia.

6. Pola pembelajaran berbasis massal menjadi kebutuhan pelanggan (users) dengan 
memperkuat pengembangan potensi khusus yang dimiliki setiap peserta didik.

7. Pola pembelajaran ilmu pengetahuan tunggal (monodiscipline) menjadi pembelajaran ilmu pengetahuan jamak (multidisciplines).

8. Pola pembelajaran pasif menjadi pembelajaran kritis.

Sebagaimana telah disebutkan diatas, pembelajaran adalah proses interaksi peserta didik dengan pendidik dan sumber belajar pada suatu lingkungan belajar. Berdasarkan pola tersebut, selain kurikulum yang baik dan siswa yang aktif dalam belajar, dibutuhkan juga guru yang mampu menciptkan suasana belajar efektif dan kondusif, sehingga potensi peserta didik (kognitif, afektif dan psikomotor) dapat berkembang secara optimal.

Untuk memperoleh prestasi belajar yang tinggi, ketiga komponen belajar tersebut (peserta didik, pendidik dan sumber belajar) harus sinergis dalam proses pembelajaran. Masih rendahnya prestasi belajar siswa, disinyalir karena belum sinergisnya ketiga kompenen tersebut. Model pembelajaran monoton dan kurang menarik, dapat menyebabkan minat belajar siswa rendah dan proses pembelajaran tidak berjalan efektif. Model pembelajaran yang tidak sesuai dengan karakteristik materi pelajaran dapat juga menyebabkan siswa kesulitan untuk memahami/meraih target pembelajaran yang ditetapkan. Tidak sinergisnya ketiga kompeonen tersebut dan menyebabkan proses belajar mengajar berjalan tidak efektif dan tidak menyenangkan serta prestasi belajar siswanya rendah, dapat pula disebabkan oleh faktor-faktor lainnya.

Berdasarkan uraian diatas, penulis ingin mencoba menemukan suatu model pembelajaran khususnya untuk mata pelajaran bahasa Indonesia materi pokok teks eskposisi yang dapat berjalan efektif, menarik dan dapat meningkatkan prestasi belajar siswa melalui Penelitian Tindakan Kelas (PTK).

\section{Pengertian Prestasi Siswa}

Prestasi belajar adalah serangkaian kalimat yang terdiri dari dua kata yaitu prestasi dan belajar, dimana kedua kata tersebut saling berkaitan serta mempunyai pengertian yang berbeda. Suatu prestasi tidak akan dapat dicapai jika kita melakukan kegiatan tidak dengan sungguh-sungguh, seperti membalikkan telapak tangan. Prestasi didapat dari perjuangan yang gigih, menghalau berbagai rintangan, yang disertai keuletan dan optimisme.

Prestasi adalah hasil dari suatu kegiatan yang telah dikerjakan atau diciptakan, sedangkan belajar adalah proses perubahan tingkah laku pada diri seseorang berkat pengalaman dan pelatihan yang didapat dari interaksi individu dengan lingkungannya. Berikut definisi - definisi tentang prestasi belajar menurut beberapa ahli, yaitu:

- Sumadi

Suryabrata, Prestasi

Belajar adalah nilai sebagai rumusan yang diberikan guru bidang studi mengenai kemajuan atau prestasi belajar selama masa tertentu. (Sumadi Suryabrata, 1998)

- Siti Pratini, Prestasi Belajar adalah suatu hasil yang dicapai seseorang dalam melakukan kegiatan belajar. (Siti Pratini, 2005)

- Kamus Bahasa Indonesia yang dinamakan Prestasi adalah hasil yang telah dicapai, dilakukan, dikerjakan dan sebagainya. 
- Bukhari M.Ed, Prestasi dapat kita artikan sebagai hasil yang telah dicapai atau hasil yang sebenarnya dicapai. (Bukhari M, 1983)

- WS. Winkel, Prestasi belajar merupakan hasil belajar yang ditampakkan oleh siswa berdasarkan kemampuan internal yang diperoleh sesuai dengan tujuan instruksional. (Winkel WS, 1989).

Dari pendapat para ahli tentang Pengertian Prestasi Belajar, maka dapat disimpulkan bahwa Prestasi Belajar adalah hasil yang dicapai atau ditunjukkan oleh peserta didik sebagai hasil belajarnya yang diperoleh melalui pengalaman dan latihan. Hal ini biasanya berupa angka-angka, huruf, serta tindakan yang dicapai masing-masing peserta didik dalam waktu tertentu.

Berdasarkan pengertian-pengertian tentang prestasi belajar di atas dapat disimpulkan bahwa prestasi belajar peserta didik tidak selamanya merupakan gambaran dari kemampuan yang sebenarnya, maksudnya prestasi belajar di sekolah tidak selalu diwujudkan dengan kecakapankecakapan, namun kecakapan itu hanya merupakan sabagian dari unsur pertumbuhan, dan pembentukan dari suatu prestasi belajar.

Suatu aktifitas dapat dikategorikan suatu prestasi belajar apabila terpenuhinya unsur-unsur di bawah ini:

1. Adanya perubahan tingkah laku.

2. Perubahan terjadi dari hasil latihan atau pengalaman.

3. Perubahan itu menyangkut beberapa aspek, yaitu aspek Kognitif, Afektif, dan Psikomotorik.

Kemampuan-kamampuan peserta didik dalam proses belajar mengajar oleh Benyamin Bloom yang dikutip oleh Nana Sudjana, 2009 mengklasifikasikan secara garis besar menjadi tiga ranah sebagai berikut:

\section{Ranah Kognitif}

Ranah Kognitif berkenaan dengan sikap hasil belajar intelektual yang terdiri dari enam aspek, yang meliputi pengetahuan, pemahaman, aplikasi, analisis, sintesis, dan evaluasi.

\section{Ranah Afektif}

Ranah Afektif berkenaan dengan sikap dan nilai yang terdiri dari lima aspek, yaitu kepekaan dalam menerima rangsangan, jawaban atas reaksi, penilaian,organisasi,dan internalisasi.

\section{Ranah Psikomotorik}

Ranah Psikomotorik berkenaan dengan hasil belajar keterampilan dan kemampuan bertindak individu.

\section{A. Model Pembelajaran Mencari Informasi (Information Search) Pembelajaran berbasis mencari informasi} merupakan konsep belajar yang membantu para guru mengaitkan antara materi yang diajarkan dengan situasi dunia nyata siswa dan mendorong siswa membuat hubungan antara pengetahuan yang dimilikinya dengan penerapannya dalam kehidupan mereka sebagai anggota keluarga dan masyarakat. Dalam hal ini siswa diberikan kesempatan dan keleluasaan untuk mencaari informasi sebagai sumber belajar.

Dari model pembelajaran ini diharapkan proses pembelajaran menjadi lebih bermakna bagi siswa itu sendiri, dimana siswa menjadi lebih proaktif untuk mendapatkan pengetahuan, pengalaman dan keterampilan.

Pembelajaran yang menerapkan metode mencari informasi menekankan pada aspek 
kerjasama antar individu dimana keberhasilan kerja sangat dipengaruhi oleh keterlibatan dari setiap anggota kelompok itu sendiri. Intinya menggunakan metode mencari informasi ini kerjasama antar anggota kelompok diutamakan, dimana setiap anggota kelompok mempunyai tanggungjawab secara individu sekaligus kelompok, sehingga dari perbedaan masing-masing individu dapat saling bertukar pikiran dan berinteraksi secara terbuka untuk menyelesaikan persoalan yang dihadapi.

Pencarian informasi ini dilakukan secara berkelompok kecil, yang bertujuan agar permasalahan pada materi tersebut terselesaikan dengan cepat, dan jika ada siswa yang malu bertanya kepada guru, maka siswa dapat bertanya dengan teman sekelompoknya, sehingga terjadi tukar pendapat antar anggota kelompok. Namun metode pembelajaran mencari informasi ini memiliki kelebihan dan kekurangan, sebagai berikut :

1. Kelebihan Motode Pembelajaran Mencari Informasi

Penggunaan metode mencari informasi ini memiliki kelebihan yaitu dapat membuat siswa memiliki informasi lebih tentang materi yang diajarkan serta siswa dapat memiliki daya berinkuiri dan saling bekerjasama. Menurut Nhiro (2010: kelebihan dari metode pembelajaran mencari informasi adalah sebagai berikut:

a. Siswa menjadi siap memulai pelajaran, karena siswa belajar terlebih dahulu sehingga memiliki sedikit gambaran dan menjadi lebih paham setelah mendapat tambahan penjelasan dari guru,

b. Siswa aktif bertanya dan juga akan membuat siswa mampu memberikan respon balik terhadap materi pembelajaran secara aktif, tidak harus menunggu informasi dari guru dan kegiatan pembelajaran pun jadi menyenangkan. Jadi, metode ini selain akan membuat materi yang akan diajarkan menjadi menarik, juga akan membuat siswa semakin aktif dan hasil belajar yang diinginkan pun dapat tercapai.

c. Materi dapat diingat lebih lama.

d. Kecerdasan siswa diasah pada saat siswa mencari informasi tentang materi tersebut tanpa bantuan guru.

e. Mendorong tumbuhya keberanian mengutarakan penapat secara terbuka dan memperluas wawasan melalui bertukar pendapat secara kelompok.

f. Siswa belajar memecahkan masalah sendiri secara kelompok dan saling bekerjasama".

Berdasarkan pendapat diatas dapat disimpulkan kelebihan dari metode mencari informasi adalah sebagai berikut:

a. Siswa akan lebih siap melaksanakan pembelajaran.

b. Siswa akan aktif dalam pembelajaran baik dalam bertanya ataupun member umpan balik.

c. Siswa akan lebih lama mengingat materi pelajaran.

d. Siswa akan terdorong untuk memperluas wawasannya.

e. Siswa belajar memecahkan masalah baik itu secara individu maupun kelompo

2. KekuranganMetode Pembelajaran Mencari Informasi

Menurut pendapat $\mathrm{Nhiro}_{1}$ kekurangan dari metode pembelajaran mencari informasi adalah sebagai berikut :

a. Siswa yang jarang memperhatikan atau bosan jika bahasan dalam metode tersebut 
tidak disukai pelaksanaan metode harus dilakukan oleh guru yang kreatif dan vokal, sedangkan tidak semua pendidik di Indonesia memiliki karakter tersebut,

b. Tidak semua lembaga bisa melaksanakannya, karena fasillitas harus tersedia menjadi hambatan dengan berbagai pola pikir dan karakter siswa yang berbeda - beda .

Berdasarkan pendapat diatas dapat disimpulkan bahwa kekurangan dari metode mencari informasi adalah adalah sebagai berikut:

a. Siswa cenderung akan jenuh jika guru tidak mampu kreatif dalam mengaplikasikan metode pembelajaran mencari informasi ini

b. Sekolah harus memiliki fasilitas-fasilitas yang dibutuhkan untuk mencari informasi dalam hal ini, misalkan buku-buku pelajaran harus tersedia.

\section{METODOLOGI PENELITIAN}

Penelitian ini dilaksanakan di Kelas X.IPA2 SMA Negeri 1 Sembawa Kabupaten Banyuasin. Penelitian dilaksanakan pada saat jadwal mata pelajaran Bahasa Indonesia yaitu hari Kamis pada bulan Juli dan Agustus tahun 2019. Subjek penelitan adalah siswa kelas X.IPA2 SMA Negeri 1 Sembawa Kabupaten Banyuasin yang berjumlah 29 orang, terdiri dari 7 orang putra dan 22 orang putrid. Penelitian dirancang sebanyak dua siklus, yang diawali pengambilan data melalui observasi pra siklus.

Sebelum dilakukannya penelitian, terlebih dahulu dibuat berbagai input instrumental dan media pembelajaran pendukung yang akan digunakan untuk pelaksanaan penelitian, yang diantaranya yaitu rencana pembelajaran dengan kompetensi dasar dan indikator pencapaian kompetensi sebagaimana. Selain itu akan dibuat juga perangkat pendukung yang berupa : (1). Lembar Pengamatan Siswa; (2) Lembar Observasi; (3) Lembar Wawancara; (4) Lembar Evaluasi, serta menjalin kerjasama dengan guru/teman sejawat yang akan ikut terlibat dalam penelitian.

Teknik dan Alat Pengumpulan Data

1) Teknik Pengumulan Data Teknik pengumpulan data dalam penelitian ini adalah tes, observasi dan wawacara.

- Tes, digunakan untuk mendapatkan data tentang prestasi belajar

- Observasi, digunakan untuk mengumpulkan data tentang partisipasi siswa dalam PBM dan implementasi model mencari informasi

- Wawancara, digunakan untuk mendapatkan data tentang tingkat keberhasilan implementasi model pembelajaran klarifikasi nilai

Alat Pengumpul Data

Alat pengumpul data dalam Penelitian Tindakan Kelas ini meliputi :

○ Tes : menggunakan butir-butir soal/instrumen soal untuk mengukur hasil belajar siswa

- Observasi : menggunakan lembar observasi untuk mengukur tingkat partisipasi siswa dalam proses belajar mengajar.

- Wawancara : menggunakan panduan wawancara untuk mengetahui pendapat atau sikap siswa tentang model pembelajaran mencari informasi

o Kuesioner : untuk mengetahui pendapat atau sikap siswa tentang model pembelajaran mencari informasi.

A. Analisis Data

Dalam penelitian ini kegiatan observasi dianalisis secara deskriptif dan komperatif. Hasil observasi yang telah dilakukan diolah dan dianalisis secara 
deskriptif dan komperatif yaitu dengan membandingkan nilai antar siklus maupun indikator dalam penelitian. Observasi dengan analisis deskriptif berdasarkan hasil observasi dan refleksi tiap siklus.

1. Aktivitas siswa: dengan menganalisis tingkat keaktifan siswa dalam proses belajar mengajar.

2. Hasil belajar : dengan menganalisis nilai ratarata ulangan harian.

3. Implementasi model pembelajaran klarifikasi nilai : dengan menganalisis tingkat keberhasilan implementasi model pembelajaran mencari informasi.

B. Prosedur Penelitian

Penelitian dirancang dengan dengan dua putaran/siklus sebagai berikut :

1) Siklus I

a) Perencanaan (planing)

○ Tim peneliti menganalisis kurikulum untuk mengetahui kompetensi dasar yang akan disampaikan kepada siswa dengan menggunakan model pembelajaran mencari informasi.

- Membuat rencana model pembelajaran mencari informasi

- Membuat instrumen yang akan digunakan pada model pembelajaran mencari informasi

- Menyusun alat evaluasi pembelajaran b) Pelaksanaan (Action)

- Guru memastikan tersedianya referensi terkait materi pokok pelajaran (teks eksposisi) di kelas, perpustakaan sekolah dan/atau internet.

- Guru menyusun kompetensi materi pokok tersebut

- Guru membuat pertanyaan untuk memperoleh kompetensi tersebut

- Guru membagi siswa menjadi kelompok kecil (maksimal 3 orang)
- Guru meminta masing-masing kelompok mencari bahan terkait di perpustakaan atau internet (yang telah dipastikan oleh guru bahwa bahan tersebut ada) dengan dibatasi waktu (missalnya 20 menit)

- Setelah siswa kembali ke kelas, guru membantu siswa membagi referensi kepada mereka.

- Siswa kemudian diminta mencari jawaban dalam referensi tersebut yang dibatasi waktu (misalnya 15 menit) oleh guru

- Hasilnya didiskusikan bersama seluruh kelas

- Guru member penjelasan dan klarifikasi tentang materi pelajaran teks eksposisi

- Guru bersama siswa menyimpulkan materi pelajaran, dan tindak lanjut

c) Pengamatan (Observation)

- Situasi kegiatan belajar mengajar

- Kemampuan siswa dalam memahami model pembelajaran mencari informasi

- Keaktifan siswa

d) Refleksi (reflection)

- Menganalisa hasil observasi pada siklus I

- Mengambil kesimpulan untuk

2) Siklus II melanjutkan ke siklus II atau tidak
a) Perencanaan (planing)
Peneliti membuat rencana pembelajaran berdasarkan hasil refleksi pada siklus I
b) Pelaksanaan (Action)
Peneliti/guru melaksanakan kegiatan belajar mengajar dengan menerapkan model pembelajaran mencari informasi berdasarkan rencana hasil refleksi siklus I
c) Pengamatan (Observation) 
Penelitia/guru

melakukan

pengamatan/observasi terhadap aktivitas

siswa dan guru dalam proses pembelajaran

d) Refleksi (reflection)

Peneliti/guru melakukan refleksi terhadap proses pembelajaran siklus kedua dan menganalisis serta membuat kesimpulan atas pelaksanaan model pembelajaran mencari informasi dan prestasi belajar siswa dalam pembelajaran mata pelajaran Bahasa Indonesia materi pokok teks eksposisi di kelas X.1 SMA Negeri 1 Sembawa Kabupaten Banyuasin.

\section{HASIL DAN PEMBAHASAN PENELITIAN}

Hasil dan pembahasan dalam penelitian diuraikan dalam tahapan penelitian siklus per siklus, sebagai berikut :

\section{A. Siklus Pertama}

Siklus pertama terdiri dari empat tahap, yaitu perencanaan, pelaksanaan, observasi dan refleksi.

(1) Siklus I ( $2 \mathrm{X}$ pertemuan)

a) Perencanaan (planing)

- Peneliti melakukan pengamatan awal terhadap hasil belajar siswa.

Kemudian melakukan analisis standar kompetensi dan kompetensi dasar yang akan disampaikan kepada siswa

- Membuat rencana pembelajaran

- Membuat media belajar

- Membuat lembar pengamatan/obsevasi penelitian

- Menyusun alat evaluasi pembelajaran

b) Pelaksanaan (Action)

Pada tahap ini, pelaksanaan penelitian belum berjalan sesuai dengan rencana.

Hal ini disebabkan :

- Sebagian siswa belum terbiasa dengan kondisi model pembelajaran mencari informasi

- Sebagian siswa belum memahami langkah-langkah model pembelajaran mencari informasi

- Siswa belum memiliki sumber belajar yang cukup untuk mendukung proses pembelajaran

- Siswa belum mampu memahami materi pembelajaran yang disampaikan secara utuh

c) Pengamatan (Observation)

1. Berdasarkan observasi aktivitas siswa dalam PBM pada siklus I, diperoleh prestasi belajar siswa melaui tes dengan 5 soal (essay jawaban terbatas) dengan KKM $\geq 62$ sebagaimana tabel berikut :

Tabel 1

\begin{tabular}{|c|c|c|c|c|}
\hline \multirow{2}{*}{ No } & \multirow{2}{*}{ Nama } & \multirow{2}{*}{$\begin{array}{c}\text { Nilai } \\
\text { didapat }\end{array}$} & \multicolumn{2}{|c|}{ Keterangan } \\
\hline & & & Tuntas & Belum \\
\hline 1 & Aisiyah Septiana & 65 & $\sqrt{ }$ & \\
\hline 2 & Andika Saputra & 67 & $\sqrt{ }$ & \\
\hline 3 & Ayu Juni Lestari & 67 & $\sqrt{ }$ & \\
\hline 4 & Bela Novalia & 79 & $\sqrt{ }$ & \\
\hline 5 & Citra Akmelia Putri & 77 & $\sqrt{ }$ & \\
\hline 6 & Dandi & 59 & & $\sqrt{ }$ \\
\hline 7 & Deri Susanto & 62 & $\sqrt{ }$ & \\
\hline
\end{tabular}




\begin{tabular}{|c|c|c|c|c|}
\hline 8 & Desi Fitriana & 59 & & $\sqrt{ }$ \\
\hline 9 & Eka Mayora & 69 & $\sqrt{ }$ & \\
\hline 10 & Felin Nuari Hadita & 79 & $\sqrt{ }$ & \\
\hline 11 & Fitriana & 64 & $\sqrt{ }$ & \\
\hline 12 & Indriani Safitri & 77 & $\sqrt{ }$ & \\
\hline 13 & Junia & 64 & $\sqrt{ }$ & \\
\hline 14 & Maharani & 57 & & $\sqrt{ }$ \\
\hline 15 & Maya Amelia & 77 & $\sqrt{ }$ & \\
\hline 16 & Misnandi & 72 & $\sqrt{ }$ & \\
\hline 17 & M. Ivan Samino & 69 & $\sqrt{ }$ & \\
\hline 18 & Neneng Saputri & 72 & $\sqrt{ }$ & \\
\hline 19 & Nova Eliza & 57 & & $\sqrt{ }$ \\
\hline 20 & Rani Yunda Lestari & 69 & $\sqrt{ }$ & \\
\hline 21 & Ria Atriani & 79 & $\sqrt{ }$ & \\
\hline 22 & Rieke Mega Nurpitami & 77 & $\sqrt{ }$ & \\
\hline 23 & Rizki Pratama & 54 & & $\sqrt{ }$ \\
\hline 24 & Sintia & 62 & $\sqrt{ }$ & \\
\hline 25 & Subekti & 54 & & $\sqrt{ }$ \\
\hline 26 & Surani Tri Widiarti & 64 & $\sqrt{ }$ & \\
\hline 27 & Tito Andika P & 57 & & $\sqrt{ }$ \\
\hline 28 & Yurinda Fidayanti & 74 & $\sqrt{ }$ & \\
\hline \multirow[t]{3}{*}{29} & Yurike Andira & 77 & $\sqrt{ }$ & \\
\hline & Jumlah & 1.959 & 21 & 8 \\
\hline & Rerata & 67,55 & & \\
\hline
\end{tabular}

2. Berdasarkan data tabel diatas, nilai ratarata hasil belajar siswa mengalami peningkatan dibanding pra siklus. Namun demikian masih terdapat siswa yang memperoleh nilai dibawah KKM yaitu sebanyak 8 orang $(27,59 \%)$.

3. Hasil obserbasi aktivitas guru dalam kegiatan PBM pada siklus I masih ada kelemahan-kelemahan, diantaranya dalam hal membimbing siswa melaksanakan instruksi sesuai langkahlangkah model pembelajaran mencari informasi.

d) Refleksi dan perencanaan ulang (reflection and replanning) Belum sempurnanya penelitian pada siklus I, berdasarkan analisa data pada tahap obsevasi disebabkan oleh ;
Guru belum belum terbiasa menciptakan suasana belajar dengan menerapkan model pembelajaran mencari

Siswa juga belum teribiasa dengan model pembelajaran yang baru, hal terlihat dari hasil observasi aktivitasi siswa yang masih lambat dalam menjalankan langkah-langkah model pembelajaran mencari informasi

Rerata hasil belajar siswa sudah cukup baik (diatas KKM), namun siswa yang memperoleh nilai dibawah KKM juga masih cukup banyak, yaitu sebanyak 8 orang $(27,59 \%)$.

Untuk memperbaiki kelemahan-kelemahan pada siklus I, penelitian akan dilanjutkan dengan 
siklus II. Pada siklus II akan dilakukan perbaikanperbaikan sebagai berikut:

> Menjelaskan langkah-langkah model pembelajaran mencari informasi rinci dan mempertegas batasan watku siswa dalam referensi informasi yang butuhkan Meminta teman sejawat untuk membantu siswa dalam mencari referensi informasi

> Memberikan motivasi kepada siswa agar lebih aktif lagi dalam pembelajaran

Lebih intensif membimbing siswa yang mengalami kesulitan pembelajaran dan memberikan pengakuan/penghargan kepada siswa

(2) Siklus II (2X Pertemuan)

A. Perencanaan (planing) Pada prinsipnya, langkah-langkah penelitian pada siklus II sama dengan langkah-langkah pada siklus I. Namun pada siklus ada penambahan kegiatan perbaikan, yaitu :

○ Meminta bantuan teman sejawat untuk membantu siswa mencari referensi informasi yang dibutuhkan

- Mengintensifkan pembimbingan pada siswa dalam melaksanakan aktivitas belajarnya sesuai intruksi model pembelajaran mencari informasi
- Memberi motivasi kepada siswa agar dapat mengikuti proses belajar mengajar dengan baik dan memberi penghargaan kepada siswa yang berhasil meraih prestasi belajar tinggi

B. Pelaksanaan (acting)

Pada siklus II ini, pelaksanaan pembelajaran dengan menggunakan model pembelajaran mencari informasi sudah berjalan dengan lebih baik, hal ini terlihat dari :

$>$ Guru sudah mulai terbiasa dengan model pembelajaran yang baru (model pembelajaran mencari informasi), dan dapat menjelaskan langkah-langkah pembelajaran dengan baik dan lancar.

Siswa terlihat lebih bersemangat dan dapat melaksanakan intruksiinstruksi proses pembelajaran dengan baik.

Siswa sudah mulai lebih fokus dalam proses pembelajaran Suasana pembelajaran yang efektif dan kondusif sudah mulai tercipta.

C. Observasi (observation)

1. Hasil observasi aktivitas siswa dapat dilihat pada table 2 berikut :

\section{Tabel 2}

\begin{tabular}{|c|l|l|l|}
\hline No & Nama & Nilai & Keterangan \\
\hline
\end{tabular}




\begin{tabular}{|c|c|c|c|c|}
\hline & & didapat & Tuntas & Belum \\
\hline 1 & Aisiyah Septiana & 75 & $\sqrt{ }$ & \\
\hline 2 & Andika Saputra & 77 & $\sqrt{ }$ & \\
\hline 3 & Ayu Juni Lestari & 77 & $\sqrt{ }$ & \\
\hline 4 & Bela Novalia & 89 & $\sqrt{ }$ & \\
\hline 5 & Citra Akmelia Putri & 87 & $\sqrt{ }$ & \\
\hline 6 & Dandi & 69 & $\sqrt{ }$ & \\
\hline 7 & Deri Susanto & 72 & $\sqrt{ }$ & \\
\hline 8 & Desi Fitriana & 69 & $\sqrt{ }$ & \\
\hline 9 & Eka Mayora & 79 & $\sqrt{ }$ & \\
\hline 10 & Felin Nuari Hadita & 89 & $\sqrt{ }$ & \\
\hline 11 & Fitriana & 74 & $\sqrt{ }$ & \\
\hline 12 & Indriani Safitri & 87 & $\sqrt{ }$ & \\
\hline 13 & Junia & 74 & $\sqrt{ }$ & \\
\hline 14 & Maharani & 67 & $\sqrt{ }$ & \\
\hline 15 & Maya Amelia & 87 & $\sqrt{ }$ & \\
\hline 16 & Misnandi & 82 & $\sqrt{ }$ & \\
\hline 17 & M. Ivan Samino & 79 & $\sqrt{ }$ & \\
\hline 18 & Neneng Saputri & 82 & $\sqrt{ }$ & \\
\hline 19 & Nova Eliza & 67 & $\sqrt{ }$ & \\
\hline 20 & Rani Yunda Lestari & 79 & $\sqrt{ }$ & \\
\hline 21 & Ria Atriani & 89 & $\sqrt{ }$ & \\
\hline 22 & Rieke Mega Nurpitami & 87 & $\sqrt{ }$ & \\
\hline 23 & Rizki Pratama & 64 & $\sqrt{ }$ & \\
\hline 24 & Sintia & 72 & $\sqrt{ }$ & \\
\hline 25 & Subekti & 64 & $\sqrt{ }$ & \\
\hline 26 & Surani Tri Widiarti & 74 & $\sqrt{ }$ & \\
\hline 27 & Tito Andika P & 67 & $\sqrt{ }$ & \\
\hline 28 & Yurinda Fidayanti & 84 & $\sqrt{ }$ & \\
\hline \multirow[t]{3}{*}{29} & Yurike Andira & 87 & $\sqrt{ }$ & \\
\hline & Jumlah & 2.249 & 29 & 0 \\
\hline & Rerata & 77,55 & & \\
\hline
\end{tabular}

Tabel 3

Hasil Belajar Siswa Per Siklus

\begin{tabular}{|c|l|c|c|c|}
\hline No & \multicolumn{1}{|c|}{ Nama } & Pra Siklus & Siklus I & Siklus II \\
\hline 1 & Aisiyah Septiana & 61 & 65 & 75 \\
\hline 2 & Andika Saputra & 64 & 67 & 77 \\
\hline 3 & Ayu Juni Lestari & 64 & 67 & 77 \\
\hline 4 & Bela Novalia & 76 & 79 & 89 \\
\hline 5 & Citra Akmelia Putri & 74 & 77 & 87 \\
\hline 6 & Dandi & 56 & 59 & 69 \\
\hline 7 & Deri Susanto & 59 & 62 & 72 \\
\hline 8 & Desi Fitriana & 56 & 59 & 69 \\
\hline 9 & Eka Mayora & 66 & 69 & 79 \\
\hline 10 & Felin Nuari Hadita & 76 & 79 & 89 \\
\hline
\end{tabular}




\begin{tabular}{|l|l|c|c|c|}
\hline 11 & Fitriana & 61 & 64 & 74 \\
\hline 12 & Indriani Safitri & 74 & 77 & 87 \\
\hline 13 & Junia & 61 & 64 & 74 \\
\hline 14 & Maharani & 54 & 57 & 67 \\
\hline 15 & Maya Amelia & 74 & 77 & 87 \\
\hline 16 & Misnandi & 69 & 72 & 82 \\
\hline 17 & M. Ivan Samino & 66 & 69 & 79 \\
\hline 18 & Neneng Saputri & 69 & 72 & 82 \\
\hline 19 & Nova Eliza & 54 & 57 & 67 \\
\hline 20 & Rani Yunda Lestari & 66 & 69 & 79 \\
\hline 21 & Ria Atriani & 76 & 79 & 89 \\
\hline 22 & Rieke Mega Nurpitami & 74 & 77 & 87 \\
\hline 23 & Rizki Pratama & 51 & 54 & 64 \\
\hline 24 & Sintia & 59 & 62 & 72 \\
\hline 25 & Subekti & 51 & 54 & 64 \\
\hline 26 & Surani Tri Widiarti & 61 & 64 & 74 \\
\hline 27 & Tito Andika P & 54 & 57 & 67 \\
\hline 28 & Yurinda Fidayanti & 71 & 74 & 84 \\
\hline 29 & Yurike Andira & 74 & 77 & 87 \\
\hline \multicolumn{2}{|c|}{ JUMLAH } & 1.871 & 1.959 & $\mathbf{2 . 2 4 9}$ \\
\hline \multicolumn{2}{|c|}{ RATA-RATA } & 64.52 & $\mathbf{6 7 . 5 5}$ & $\mathbf{7 7 , 5 5}$ \\
\hline
\end{tabular}

2. Berdasarkan data tabel 3 diatas, nilai rerata hasil belajar siswa meningkat cukup signifikan yaitu menjadi 77,55 dibanding pada siklus I yang hanya sebesar 67,55. Begitupun dengan Hasil belajar siswa secara keseluruhan yang telah mencapai tingkat ketuntasan $100 \%$ atau tidak ada lagi siswa yang memperoleh nilai dibawah KKM $(\geq 62)$.

3. Hasil obsevasi terhadap aktivitas guru pada siklus II juga sudah lebih baik. Guru berhasil menciptakan suasana belajar yang efektif, kondusif dan dapat meningkatkan Hasil belajar siswanya sebagaimana dapat dilihat pada tabel 3 dan 4

D. Refleksi (reflection)

Pada siklus II, proses pembelajaran dengan menggunakan model pembelajaran mencari informasi telah berjalan dengan baik. Hal ini dapat dilihat dari :

> Suasana pembelajaran yang berlangsung dengan baik, efektif dan kondusif

Siswa bersemangat dalam menjalankan aktivitas belajarnya dan dapat melaksanakan intruksi guru dengan baik.

Siswa mulai dapat berpartisipasi aktif dalam kegiatan pembelajaran

Hasil belajar siswa meningkat dan tidak ada lagi siswa yang memperoleh nilai dibawah KKM $(\geq 62)$

Berdasarkan data diatas, maka penelitian pada siklus II dianggap telah berhasil menciptakan suasana belajar yang efektif dan kondusif serta dapat meningkatkan hasil berlajar siswa.

\section{KESIMPULAN DAN SARAN}

Kesimpulan 
Berdasarkan hasil penelitian tindakan kelas pada siklus I dan siklus || dengan menerapkan model pembelajaran mencari informasi dapat disimpulkan sebagai berikut

1. Pembelajaran berlangsung efektif dan kondusif

2. Siswa lebih bersemangat dan fokus dalam belajar

3. Aktivitas berpikir kritis siswa dalam proses pembelajaran terwadahi, aktivitas membangun sendiri pengetahuan dan menemukan langkah-langkah dalam mencari penyelesaian masalah tersalurkan dan mendapat apresiasi dari warga kelas

4. Hasil belajar siswa meningkat

5. Profesionalisme guru meningkat

6. Hasil penelitian dapat memperkaya khasanah keilmuan dan bermanfaat bagi guru dalam proses pembelajaran

A. Saran

1. Kurikulum 2013 (K-13) dengan paradigma pembelajaran yang berpusat pada siswa menuntut adanya guru yang mampu menciptkan suasana pembelajaran dengan siswa yang aktif belajar. Untuk itu, guru harus kreatif dan inovatif mengembangkan model pembelajaran yang sesuai dengan karateristik siswa dan karakteristik materi pelajaran.

2. Guru mata pelajaran Bahasa Indonesia hendaknya dapat menerapakan model pembelajaran mencari informasi (information serach) untuk materi pokok teks eksposisi atau yang sejenis.
3. Guru hendaknya terus mengembangkan kemampuannya dalam penelitian dan menemukan model-model pembelajaran yang dapat menciptakan suasana pembelajaran yang efektif dan kondusif.

\section{Daftar Pustaka}

Abu Ahmadi dan Widodo Supriyono. (2004). Psikologi Belajar. Jakartat: Rineka Cipta.

Djamarah, Syaiful bahri. 1994. Hasil Belajar Dan Kompetensi Guru. Surabaya : Usaha Nasional.

Djamarah, Syaiful bahri. 1994. Hasil Belajar Dan Kompetensi Guru. Surabaya : Usaha Nasional.

Gagne, Robert M. dan Leslie J. Briggs, 1979, Principles of Instructional Design, second edition, New York: Rinegart and Winson.

Peraturan Menteri Pendidikan dan Kebudayaan Nomor $81 \mathrm{~A}$ tentang Implementasi Kurikulum 2013

Sanjaya, Wina, Dr. M.Pd, 2009, Kurikulum dan Pembelajaran: Teori dan Praktek Pengembangan Kurikulum Tingkat Satuan Pendidikan (KTSP), Jakarta : Kencana.

$\begin{array}{cr}\text { Implementasi } & \text { Pembelajaran Dalam } \\ \text { Burikulum } & \text { Berbasis }\end{array}$
Kompetensi, 2008, Jakarta: Kencana.

Simon, S.B., Howe, L.W., \& Kirschenbaum, H. Values Clarification: A Handbook of Practical Strategies for Teachers and Students. New York: Hart Publishing, 1972).

Sudrajat, Akhmad, 2008, Model Pembelajaran Inovatif. http://Akhmad_Sudrajat.wordpress.com , 2008, Penelitian Tindakan Kelas (Classroom Action Research). 2008. http://Akhmad_Sudrajat.wordpress.com

------------, 2008, Pengertian Pendekatan, Strategi, Metode, Teknik, Taktik, dan Model Pembelajaran,

Syah, Muhibbin. 2000. Psikologi Pendidikan. Bandung : Rosda Karya 
